\title{
Opioid receptors: Structural and mechanistic insights into pharmacology and signaling
}

Yi Shang and Marta Filizola*

Icahn School of Medicine at Mount Sinai, Department of Structural and Chemical Biology, One

Gustave, L. Levy Place, Box 1677, New York, NY 10029, USA

\section{*Corresponding author:}

Dr. Marta Filizola

Department of Structural and Chemical Biology

Icahn School of Medicine at Mount Sinai

One Gustave L. Levy Place, Box 1677; New York, NY 10029-6574

Tel: 212-659-8690; Fax: 212-849-2456; Email: $\underline{\text { marta.filizola@ mssm.edu }}$ 


\begin{abstract}
Opioid receptors are important drug targets for pain management, addiction, and mood disorders. Although substantial research on these important subtypes of $G$ protein-coupled receptors has been conducted over the past two decades to discover ligands with higher specificity and diminished side effects, currently used opioid therapeutics remain suboptimal. Luckily, recent advances in structural biology of opioid receptors provide unprecedented insights into opioid receptor pharmacology and signaling. We review here a few recent studies that have used the crystal structures of opioid receptors as a basis for revealing mechanistic details of signal transduction mediated by these receptors, and for the purpose of drug discovery.
\end{abstract}

Key words: GPCRs, opioid binding, receptor, molecular dynamics, allosteric modulators, virtual screening, functional selectivity, dimerization. 


\section{Introduction}

Opioid receptors belong to the super-family of G-protein coupled receptors (GPCRs), which are by far the most abundant class of cell-surface receptors, and also the targets of about one-third of approved/marketed drugs (Vortherms and Roth, 2005). Residing in different parts of the body (e.g., brain, spinal cord, digestive tract, etc.), opioid receptors are widely studied due to their crucial role in pain management (Pasternak, 2014), drug abuse/addiction (Kreek et al., 2012), and mood disorders (Lutz and Kieffer, 2013). There are three major subtypes of opioid receptors: $\delta$ receptor, $\mu$ receptor, and $\kappa$ receptor. These receptors are activated by endogenous peptides such as endomorphins, enkephalins, and dynorphins, but also by naturally occurring alkaloids and other semi-synthetic and synthetic small-molecule ligands (McCurdy et al., 2003). Although a fourth receptor subtype, i.e., the nociceptin opioid receptor (NOP receptor), is phylogenetically related to $\delta$ receptor, $\mu$ receptor, and $\kappa$ receptor, it does not bind the same ligands.

In addition to their still unbeatable analgesic effects, opioid drugs are accompanied by a variety of undesirable side effects, including vomiting, nausea, constipation, tolerance, addiction etc. (Feng et al., 2012). Thus, substantial drug discovery efforts have been devoted over the years to reduce the disadvantages of these drugs while retaining their therapeutic efficacy. In the absence of high-resolution crystal structures of opioid receptors until 2012, the majority of these efforts used ligand-based strategies, although some also resorted to rudimentary molecular models of the receptors based on relatively distant structural templates. Notwithstanding this substantial amount of work over the course of several years, safe and effective opioid ligands remain the holy grail of the pharmaceutical industry. 
The recent advances in membrane protein crystallization (Chun et al., 2012), which enabled the determination of various high-resolution crystal structures of GPCRs, including those of all four opioid receptor subtypes (Fenalti et al., 2014; Granier et al., 2012; Manglik et al., 2012; Thompson et al., 2012; Wu et al., 2012) (see Figure 1), marked the beginning of a new era in opioid research. By revealing important details of ligand-receptor interactions at the orthosteric binding site (i.e., the site at which endogenous opioid ligands bind), or allosteric sites (e.g., the much anticipated sodium binding site (Fenalti et al., 2014)), these structures evidently offer new opportunities for drug discovery at opioid receptors (Filizola and Devi, 2013). Notably, comparison between the four opioid receptor crystal structures (Filizola and Devi, 2013) reveals common ligand-receptor interactions that may be responsible for the molecular recognition of classical opioid drugs. In contrast, the different ligand-receptor interactions that are mostly located at the extracellular side of the receptor may be responsible for the specificity of the ligands for a given receptor subtype. Among them are the interactions crystallographic ligands of $\mu$ receptor and $\delta$ receptor form with residues of the transmembrane (TM) helices TM6 and/or TM7, or those that the crystallographic ligands of $\kappa$ receptor and NOP receptor form with TM2 and TM3 residues.

Additional, important details of opioid receptor binding and signaling were provided by the ultra-high resolution crystal structure of $\delta$ receptor (Fenalti et al., 2014), which only recently appeared in the literature. In particular, this structure revealed the presence of an allosteric binding site occupied by sodium, which had been suggested to serve as an allosteric modulator of opioid receptors for quite some time (Pasternak and Snyder, 1975), and was recently found in ultra-high resolution crystal structures of other GPCRs (Katritch et al., 2014b; Liu et al., 2012). In all these ultra-high resolution crystal structures, this ion is located near the conserved D2.50 
residue, which is about $10 \AA$ below the D3.32 residue that interacts with several orthosteric ligands of GPCRs, including classical opioid ligands (note that all the residues mentioned in this manuscript are numbered according to the Ballesteros-Weinstein generic numbering scheme (Ballesteros and Weinstein, 1995)).

Although a detailed knowledge of the crystal structures of opioid receptors provides a new dimension for structure-guided drug discovery efforts, the realizations that these receptors are rather dynamic systems and that several opioid ligands can activate multiple signaling pathways add another level of complexity to an already complicated problem. Various cases of so-called functional selectivity or biased agonism, primarily through $\mathrm{G}_{\mathrm{i} / \mathrm{o}}$ or arrestin, have been reported in the literature for all major opioid receptors (e.g., see (Luttrell, 2014; Thompson et al., 2014; Thompson et al., 2015; Violin et al., 2014) for recent reviews). This selectivity in opioid receptor signaling and function may be achieved through i) conformational preferences induced by ligands with different efficacies binding at the orthosteric site and inducing coupling of an intracellular protein over another, ii) bias in the downstream functional outcome, iii) allosteric modulation of the efficacy of orthosteric ligands, and/or iv) dimerization/oligomerization of opioid receptors among themselves or with other GPCRs (e.g., see (Fujita et al., 2014) for a recent review). Based on recently reported examples (e.g., see (Chen et al., 2013; DeWire et al., 2013; Soergel et al., 2014a; Soergel et al., 2014b)), it appears that developing biased opioid ligands for one intracellular signaling pathway or another may provide a more effective route to analgesics with reduced side effects.

We summarize here a few studies that have been inspired by the new structural information available for opioid receptors, and their impact on both a mechanistic understanding of opioid receptor function and rational drug discovery. 


\section{Structure-based drug design at the orthosteric site using opioid receptor crystal structures}

Compared to the shallow pockets of many soluble proteins, the more buried orthosteric binding pockets of GPCRs appear to be particularly well suited to small-molecule docking for the purpose of rational drug discovery. Additionally, chemical libraries that are typically used for virtual screening contain many GPCR binders because of the special attention GPCRs have received from medicinal chemists over the years. Thus, not surprisingly, various structure-based drug design campaigns carried out in recent years using currently available crystal structures of GPCRs have resulted in both the discovery of novel chemical scaffolds, and the optimization of lead candidates (e.g., see (Jacobson, 2013; Kooistra et al., 2014; Shoichet and Kobilka, 2012) for recent reviews).

The new crystal structures of opioid receptors bear no exception. In fact, a few examples have already appeared in the literature in which crystal structures of opioid receptors have successfully been used to provide retrospective models of the binding of known opioid ligands to their receptors (e.g., see (Martinez-Mayorga et al., 2013; Wu et al., 2012)) or to identify novel chemical scaffolds binding at the orthosteric site from virtual screening (e.g., see (Negri et al., 2013)). These examples mostly refer to $\kappa$ receptor, whose ligands may play a significant role in pain management, anxiety, depression, stress, and psychotic behavior without activating the reward pathway (Vanderah, 2010; Wang et al., 2010).

A number of investigators have used various computational tools, including molecular docking, molecular dynamics (MD), free-energy perturbations, and ab initio calculations (e.g., see (Goldfeld et al., 2015; Leonis et al., 2014; Martinez-Mayorga et al., 2013; Polepally et al., 
2014; Vardy et al., 2013; Wu et al., 2012)) to provide a molecular description of both the binding and function of selective $\kappa$ receptor ligands at the $\kappa$ receptor crystal structure, in relation to the crystallographic binding pose of the highly selective antagonist JDTic ((3R)-1,2,3,4-tetrahydro7-hydroxy-N-[(1S)-1-[[(3R,4R)-4-(3-hydroxyphenyl)-3,4-dimethyl-1-piperidinyl]methyl]-2methylpropyl]-3-isoquinolinecarboxamide) (Wu et al., 2012). For instance, comparison of the predicted poses of the $\kappa$ receptor selective morphine-based antagonists nor-binaltorphimine (norBNI) and 5'-guanidinonaltrindole (GNTI) with the crystallographic pose of JDTic emphasized the role of $\kappa$ receptor residues V2.53 ( $\mathrm{A}$ in $\mu$ and $\delta$ receptors), V2.63 ( $\mathrm{N}$ in $\mu$ receptor and $\mathrm{K}$ in $\delta$ receptor), $\mathrm{I} 6.55$ ( $\mathrm{V}$ in $\mu$ and $\delta$ receptors), and $\mathrm{Y} 7.35$ (W in $\mu$ receptor and $\mathrm{L}$ in $\delta$ receptor) as molecular determinants of the binding selectivity of JDTic for $\kappa$ receptor (Wu et al., 2012). In contrast, E6.58 appeared to be the only $\kappa$ receptor residue that most likely confers $\kappa$ receptor selectivity to nor-BNI and 5'-GNTI. Docking studies (Vardy et al., 2013) of $\kappa$ receptor selective agonists representing four different chemotypes, including a peptide (dynorphin A), an arylacetamide (U-69593), a non-nitrogenous diterpene (salvinorin A), and an octahydroisoquinolinone carboxamide (1xx), inspired functional assays on mutants at eighteen positions of the putative agonist binding site within the $\kappa$ receptor crystal structure. Analysis of the experimental data indicated differential effects of the mutated residues on binding and function (Vardy et al., 2013). For instance, the D3.32A mutation dramatically decreased the affinity of the basic amine-containing agonists dynorphin A and U-69593, but not that much the affinity of the non-basic compounds $1 \mathrm{xx}$ and salvinorin A. Similarly, D3.32N decreased the affinity of dynorphin A and U-69593, but caused an increase in both the affinity and potency of compounds 1xx and salvinorin A. Notably, some mutations (e.g., at Y3.33, M3.36, Y7.43, Y7.35, and K5.39) appeared to affect function more than binding, and were suggested to be 
directly involved, along with crystallographic water molecules, in signal transduction propagated through specific conformational changes in the receptor (Vardy et al., 2013). The role of the water structure within the $\kappa$ receptor active site was also emphasized in another recent study motivated by the apparent failure of two established scoring functions (Glide SP and Glide XP) to effectively distinguish between $\kappa$ receptor binders and decoys (Goldfeld et al., 2015). This observation prompted the development of a new empirical scoring function, WScore, to assess interactions between ligands and water molecules at an active site.

The $\kappa$ receptor crystal structure was also recently used to rationalize the binding of several different derivatives of the selective non-nitrogenous diterpene $\kappa$ receptor agonist salvinorin A (Polepally et al., 2014), including 22-thiocyanatosalvinorin A (RB-64) (Wu et al., 2012). A model of the latter was based on previous experimental evidence suggesting that the agonist 2-acetoxy moiety forms an irreversible, covalent bond with the $\kappa$ receptor residue C7.38. According to this docking hypothesis, the fused tricyclic scaffold of salvinorin $\mathrm{A}$ is oriented towards TM2, while the C-2 acetoxy group of the ligand is accommodated in a pocket surrounded by residues D3.32, Y3.33 and M3.36. Different was the case for the recently synthesized series of salvinorin A derivatives containing potentially reactive Michael acceptor functional groups at the C-2 position (Polepally et al., 2014), which cannot form an irreversible bond with $\mathrm{C} 7.38$. While the predicted binding was somehow similar to that of salvinorin A, the bulky substitutions at the $\mathrm{C}-2$ position could not be accommodated in the same pocket, and led to a decreased affinity of the ligands for $\kappa$ receptor. Notably, the polarity introduced by a substitution with a heterocyclic nitrogen atom made the ligand loose affinity for the $\kappa$ receptor while gaining it at the $\mu$ receptor. A possible explanation for this $\kappa / \mu$ receptor selectivity is that the ligand adopts an alternative binding mode in the $\mu$ receptor stabilized by an interaction with 
the non-conserved residue $\mathrm{N} 2.63$ ( $\mathrm{V}$ in $\kappa$ receptor and $\mathrm{K}$ in $\delta$ receptor) (Polepally et al., 2014). MD simulations, free energy, and $a b$ initio calculations of the $\kappa$ receptor crystal structure in complex with salvinorin A or JDTic showed that the ligands are stabilized within the binding pocket through interactions with different residues (Leonis et al., 2014).

In addition to provide insights into the molecular determinants required for ligand binding to opioid receptors, the high-resolution crystal structures of these receptors can be used in virtual screening campaigns to identify novel compounds. To the best of our knowledge, to date, ours is the only published example of a virtual screening performed using the crystal structure of an opioid receptor that led to the identification of novel ligands. Specifically, using the $\kappa$ receptor crystal structure, we screened in silico over 4.5 million "lead-like" small molecules from the ZINC database (Negri et al., 2013) at the crystallographic orthosteric site of the receptor. Following a series of criteria, including novelty, interaction with $\kappa$ receptor residues that are different from $\mu$ and $\delta$ receptors, and limited flexibility, we purchased 22 small molecules for experimental testing. Although the used $\kappa$ receptor crystal structure corresponds to an inactive conformation of the receptor, we identified a selective, $\kappa$ receptor agonist in this study. As this compound does not resemble the chemotype of a classical opioid ligand, there is every expectation that it may be developed into improved medications. To this end, additional, collaborative studies are ongoing in our lab.

\section{Allosteric modulators of the binding and/or signaling efficacy of opioid receptor orthosteric ligands.}

Limiting the search for novel opioid receptor ligands to the orthosteric site may not be the best strategy to achieve drug selectivity because of the evolutionary pressure orthosteric sites 
face to accommodate endogenous ligands. Targeting allosteric sites on the receptor, i.e., sites that are topographically different from those recognizing endogenous ligands, and therefore less conserved in their amino acid sequences, represents an attractive alternative to achieve greater selectivity. Allosteric modulators of GPCRs range from small organic molecules or peptides, to ions and lipids (Christopoulos, 2014b). They can bind at the receptor extracellular side, inside the TM helical bundle, or even at the intracellular part of the receptor (Shukla, 2014). Based on the positive (i.e., increase), negative (i.e., decrease), or neutral effect they have on the affinity and/or efficacy of the orthosteric ligand, allosteric modulators of GPCRs are termed positive allosteric modulators (PAMs), negative allosteric modulators (NAMs), or silent allosteric modulators (SAMs), respectively. The latter do not have any effect on the affinity and/or efficacy of the orthosteric ligand, yet they share the same allosteric binding pocket of, and therefore can compete with, PAMs or NAMs. Whichever the effect induced by the allosteric modulator, its magnitude and/or direction strongly depend on the orthosteric ligand that is used to probe receptor function, according to a phenomenon that has been termed in the literature "probe dependence' (e.g., see (Christopoulos, 2014a). This is one of the reasons that make allosteric modulators standout candidates for drug discovery, alongside their possibly improved selectivity, their maintenance of the temporal and spatial characteristics of endogenous signals, their potential for biased signaling, and their possibly reduced on-target overdosing risks given that their effect is limited to ligand cooperativity.

Like other GPCRs (Katritch et al., 2014a), allosteric modulators of opioid receptors can be as small as ions. As early as in the '70s (Pasternak and Snyder, 1975; Pert et al., 1973; Preininger et al., 2013), physiological concentrations of sodium were shown to decrease the binding of agonists, but not antagonists, to the opioid receptors (e.g., see (Pasternak and Pan, 
2013)). Notably, manganese ions restored full agonist binding to $\mu$ receptor in the presence of sodium, but did not have any effect on the binding of antagonists (Pasternak et al., 1975). That an ion actually binds to an opioid receptor was demonstrated for the first time unambiguously by the very recent ultra-high resolution crystallographic structure of $\delta$ receptor (PDB: 4N6H (Fenalti et al., 2014)). This structure revealed a sodium ion forming a salt bridge with the GPCR family A conserved residue D2.50, as well as additional polar interactions with two water molecules and receptor side chains S3.39 and N3.35. Notably, site-directed mutagenesis and functional studies of mutants of these sodium-coordinating residues revealed that they act as 'efficacy switches' at the $\delta$ receptor as they either augmented constitutive $\beta$-arrestin-mediated signaling or transformed classical $\delta$ receptor antagonists (e.g., naltrindole) into potent $\beta$-arrestinbiased agonists (Fenalti et al., 2014).

To provide mechanistic detail into the sodium control of opioid receptor binding and signaling, we recently carried out extensive all-atom MD simulations to explore the dynamic nature of sodium binding to the crystal structures of $\delta, \mu$, and $\kappa$ receptors (Shang et al., 2014) in an explicit lipid-water environment. According to these simulations, sodium enters all three opioid receptors exclusively from the extracellular side, and within a few hundred nanoseconds it forms a stable coordination with the residues seen crystallographically (Fenalti et al., 2014), passing through the orthosteric site. Another recent MD study of the $\mu$ receptor crystal structure (Yuan et al., 2013) also concluded that sodium enters preferentially from the extracellular side, and it binds to the crystallographic site defined by residue D2.50. In our simulations, the experimentally-observed inhibition of agonist binding by sodium was attributed to the extended hydrogen bond network that puts into communication the orthosteric and allosteric sites, and contributes to the stability of an inactive conformation of the receptor (Shang et al., 2014). Using 
random accelerated molecular dynamics, we also predicted possible egress pathways of the ion from the receptor, which included both extracellular and intracellular pathways (Shang et al., 2014).

Recent high-throughput screening campaigns using a $\beta$-arrestin recruitment assay have successfully identified small-molecule allosteric modulators of $\mu$ and $\delta$ receptors (Burford et al., 2013; Burford et al., 2014a; Burford et al., 2014b). Further characterization of these compounds using additional functional assays, such as adenylyl cyclase activity inhibition and G protein activation, confirmed these ligands as $\mu$-receptor-selective PAMs. Further studies are ongoing in our lab to predict the energetically preferred binding poses of these ligands at putative allosteric binding pockets within the $\mu$ receptor crystallographic structure. Figure 2 provides a preliminary idea of binding pockets within the crystal structures of the major $\delta, \mu$, and $\kappa$ receptor subtypes as assessed by FTMAP (Brenke et al., 2009), an efficient Fast Fourier Transform correlation approach that allows to sample billions of probe positions on a protein, and to predict 'hot spots' or putative binding pockets for small molecules based on the common location of several probe clusters. Specifically, 8 to 10 probe clusters are identified by FTMAP for the different receptor subtypes we studied, ranging from 1 to 28 probes per cluster. Notably, the majority of probe clusters nicely overlaps with the crystallographic ligands, and at least three main pockets are identified by FTMAP in the extracellular region of the receptors. These correspond to the orthosteric site of morphinans surrounded by helices TM3, TM5, TM6, and TM7 (site 1 in Figure 2), its extension between TM2 and TM3 as revealed by the JDTic-bound $\kappa$ receptor crystal structure (site 2 in Figure 2), and a third pocket delimited by TM1, TM2, and TM7 (site 3 in Figure 2). The latter two sites are likely to correspond to allosteric sites for some ligands, or may even represent pockets for metastable states along the ligand binding pathway. 


\section{Functional selectivity at opioid receptors}

The concept of functional selectivity or biased GPCR signaling (e.g., see (Shonberg et al., 2014; Violin et al., 2014) for recent reviews) has changed the traditional two-state model of receptor activation in that multiple conformations are assumed to be differentially stabilized by ligands with different efficacy as a prerequisite to activating $\mathrm{G}$ protein-dependent or independent (e.g., through $\beta$-arrestin) signaling pathways, thus resulting in beneficial or adverse effects. This appears to be also the case for opioid receptors (e.g., see (Raehal and Bohn, 2014; Raehal et al., 2011; Thompson et al., 2015; Williams et al., 2013), where morphine was the first ligand to be shown a) to function as a weak internalizer notwithstanding its efficacy in mediating G protein activation (Keith et al., 1996; Sternini et al., 1996), and b) to exert enhanced analgesia and reduced respiratory depression and constipation in a $\beta$-arrestin2 knockout mouse (Raehal et al., 2005). These observations prompted additional studies to identify functionally selective opioid receptor ligands, and to understand which signaling pathway(s) regulated their beneficial and adverse effects. For instance, recent evidence suggests that while $\kappa$ receptor agonists may in principle be developed into effective analgesics without a high abuse potential, their often associated dysphoria (Land et al., 2009), a side effect that has been suggested to be related to the activation of the arrestin pathway (Chavkin, 2011), limits their clinical development. Taken together, these results suggest that biased opioid ligands towards the G-protein pathway and away from the $\beta$-arrestin pathway may hold greater potential as future opioid receptor therapeutics (Raehal and Bohn, 2014). Thus, data from studies that attempt to quantify biased agonism at opioid receptors (e.g. see (Frolich et al., 2011; McPherson et al., 2010; Molinari et al., 2010; Rivero et al., 2012; White et al., 2014; Zhou et al., 2013), especially in the context of 
tissues, organs, and the whole animal (Zhou and Bohn, 2014), are in high demand (Thompson et al., 2015).

Among the most recently characterized chemical scaffolds with a range of signaling bias in vitro are several $\kappa$ receptor agonists (e.g., see (White et al., 2014; Zhou et al., 2013)). These compounds range from endogenous peptides and diterpene scaffolds, which are all G-protein biased, to arylacetamide compounds which are both G-protein and $\beta$-arrestin biased ligands (White et al., 2014), to triazole and isoquinoline analogues, which preferentially activate the G protein pathway with minimal effects on $\beta 2$-arrestin recruitment (Zhou et al., 2013). It will be of great interest to see whether simple information from docking of these compounds to the crystal structure of $\kappa$ receptor is sufficient to identify the key molecular determinants that are responsible for functional selectivity at the G-protein or $\beta$-arrestin signaling pathway. A complete understanding of the conformational changes in the receptor induced by the two sets of differently biased ligands may be necessary to elucidate functional selectivity at opioid receptors.

That conformational plasticity may be an important contributor of functional selectivity is not surprising. Like other GPCRs, opioid receptors are intrinsically flexible molecules, and the mechanistic properties of their crystal structures have been recently investigated by MD simulations at the sub-microsecond and microsecond time scales (e.g., see (Fossepre et al., 2014; Shang et al., 2014; Shim et al., 2013a)). Simulations of the ligand-free form of $\mu$ receptor in a simplified membrane model (Fossepre et al., 2014) drew attention to both the plasticity of the receptor binding site and correlated motions between the intra- and extra-cellular regions of the receptor notwithstanding a certain rigidity of the central part of the receptor. Additional MD simulations of the $\mu$ receptor crystal structure in complex with three agonists, three antagonists, and a partial agonist, and on the constitutively active T6.34K mutant (Shim et al., 2013b) showed 
a differential involvement of D3.32 in direct interaction with the basic nitrogen of agonists compared to antagonists. These simulations also drew attention to differences in the conformational properties of the intracellular region of the receptor when bound to agonists or antagonists. Further studies are necessary to understand how biased agonists affect the conformation properties of the receptor, and what conformation(s) they preferentially stabilize.

Notwithstanding the number of known biased agonists of opioid receptors and the interest in understanding their effect on the conformational plasticity of the receptor, there is no indication for the majority of these compounds that they may result in improved therapeutics. The G protein-biased $\mu$ receptor ligand TRV130 (3-methoxythiophen-2-yl)methyl](\{2-[(9R)-9(pyridin-2-yl)-6-oxaspiro[4.5]decan-9-yl]ethyl\})amine) (Chen et al., 2013; DeWire et al., 2013) represents an exception as it was recently demonstrated to be an improved analgesic with reduced side effects (i.e., respiratory suppression and nausea) compared to morphine (Soergel et al., 2014a; Soergel et al., 2014b) as it entered Phase II of drug development. Given its potential clinical relevance, a thorough understanding of the molecular basis of the TRV-130 action is highly desirable, and the availability of the $\mu$ receptor crystal structure offers an unprecedented opportunity to advance knowledge in that direction.

\section{Opioid receptor dimerization}

Like for other GPCRs, the possibility that opioid receptors form physiologically relevant dimers/oligomers has been suggested more than once (e.g., see (Ferre et al., 2014) for a recent review), notwithstanding the still active fierce debate that exists on the topic of oligomerization of family A GPCRs (e.g., see (Bouvier and Hebert, 2014a, b; Lambert and Javitch, 2014a, b)). The several recent crystal structures that show interacting parallel receptors in the crystal unit 
cell (Figure 3) have been used as an argument in favor of GPCR dimerization, although the possibility exists that these are crystallographic artifacts and/or they do not necessarily represent physiologically relevant interfaces.

Two of the five available opioid receptor crystal structures (Fenalti et al., 2014; Granier et al., 2012; Manglik et al., 2012; Thompson et al., 2012; Wu et al., 2012), specifically the structures of $\mu$ (Manglik et al., 2012) and $\kappa(\mathrm{Wu}$ et al., 2012) receptors, also reveal parallel arrangements of interacting receptors. As shown in Figure 3, these correspond to two different interfaces in the case of $\mu$ receptor, one of which is also seen in the $\kappa$ receptor crystal structure. Specifically, the interface that is unique to the $\mu$ receptor (herein called the TM5,6/TM5,6 interface) is made of symmetric interactions between TM5 and TM6 helices. The other interface that is common to both $\mu$ and $\kappa$ receptors (herein called the TM1,2,H8/TM1,2,H8 interface), although slightly different between the two, involves TM1, TM2, and helix 8 (H8). Notably, biochemical experiments suggested the involvement of TM1 (He et al., 2011), as well as TM4/TM5 (Johnston et al., 2011), or the carboxyl tail and the intracellular loop 3 in the dimerization of opioid receptors (O'Dowd et al., 2012).

To investigate the relative stability of the $\mu$ and $\kappa$ receptor crystallographic interfaces in an explicit lipid-water environment, and in the absence of the T4L replacing the intracellular loop 3 in the crystal structure, we recently carried out umbrella sampling MD simulations of coarse-grained representations of the opioid receptor crystallographic dimers (Johnston and Filizola, 2014). We found that these interfaces are indeed viable dimeric configurations in an explicit membrane environment, as they appear to be in general, quite stable from a thermodynamic view point. Whether or not these interfaces are more kinetically favorable than others, and would occur in vivo remains to be assessed. To facilitate experimental testing, our 
studies provide specific testable hypotheses of residues that, if mutated, might either increase or decrease the strength of opioid receptor dimerization (Johnston and Filizola, 2014).

\section{Acknowledgements}

Funding for this work was provided by National Institutes of Health grants DA026434 and DA034049. Computations in the Filizola lab are performed on the Extreme Science and Engineering Discovery Environment (XSEDE) under MCB080109N, which is supported by National Science Foundation grant number OCI-1053575, and on the computational resources provided by the Scientific Computing Facility at the Icahn School of Medicine at Mount Sinai. 


\section{References}

Ballesteros, J., Weinstein, H., 1995. Integrated methods for the construction of three-dimensional models and computational probing of structure-function relations in $\mathrm{G}$ protein-coupled receptors. Elsevier, pp. 366-428.

Bouvier, M., Hebert, T.E., 2014a. CrossTalk proposal: Weighing the evidence for Class A GPCR dimers, the evidence favours dimers. The Journal of physiology 592, 2439-2441.

Bouvier, M., Hebert, T.E., 2014b. Rebuttal from Michel Bouvier and Terence E. Hebert. The Journal of physiology 592, 2447.

Brenke, R., Kozakov, D., Chuang, G.Y., Beglov, D., Hall, D., Landon, M.R., Mattos, C., Vajda, S., 2009. Fragment-based identification of druggable 'hot spots' of proteins using Fourier domain correlation techniques. Bioinformatics 25, 621-627.

Burford, N.T., Clark, M.J., Wehrman, T.S., Gerritz, S.W., Banks, M., O'Connell, J., Traynor, J.R., Alt, A., 2013. Discovery of positive allosteric modulators and silent allosteric modulators of the mu-opioid receptor. Proceedings of the National Academy of Sciences of the United States of America 110, 10830-10835.

Burford, N.T., Traynor, J.R., Alt, A., 2014a. Positive allosteric modulators of the mu-opioid receptor: a novel approach for future pain medications. British journal of pharmacology.

Burford, N.T., Wehrman, T., Bassoni, D., O'Connell, J., Banks, M., Zhang, L., Alt, A., 2014b. Identification of Selective Agonists and Positive Allosteric Modulators for mu- and deltaOpioid Receptors from a Single High-Throughput Screen. Journal of biomolecular screening. 
Chavkin, C., 2011. The therapeutic potential of kappa-opioids for treatment of pain and addiction. Neuropsychopharmacology : official publication of the American College of Neuropsychopharmacology 36, 369-370.

Chen, X.T., Pitis, P., Liu, G., Yuan, C., Gotchev, D., Cowan, C.L., Rominger, D.H., Koblish, M., Dewire, S.M., Crombie, A.L., Violin, J.D., Yamashita, D.S., 2013. Structure-activity relationships and discovery of a $\mathrm{G}$ protein biased mu opioid receptor ligand, [(3methoxythiophen-2-yl)methyl](\{2-[(9R)-9-(pyridin-2-yl)-6-oxaspiro-[4.5]decanyl]ethyl\})amine (TRV130), for the treatment of acute severe pain. J Med Chem 56, 80198031.

Cherezov, V., Rosenbaum, D.M., Hanson, M.A., Rasmussen, S.G., Thian, F.S., Kobilka, T.S., Choi, H.J., Kuhn, P., Weis, W.I., Kobilka, B.K., Stevens, R.C., 2007. High-resolution crystal structure of an engineered human beta2-adrenergic G protein-coupled receptor. Science $318,1258-1265$.

Chien, E.Y., Liu, W., Zhao, Q., Katritch, V., Han, G.W., Hanson, M.A., Shi, L., Newman, A.H., Javitch, J.A., Cherezov, V., Stevens, R.C., 2010. Structure of the human dopamine D3 receptor in complex with a D2/D3 selective antagonist. Science 330, 1091-1095.

Christopoulos, A., 2014a. Advances in G protein-coupled receptor allostery: from function to structure. Molecular pharmacology 86, 463-478.

Christopoulos, A., 2014b. Advances in GPCR Allostery: From Function to Structure. Molecular pharmacology.

Chun, E., Thompson, A.A., Liu, W., Roth, C.B., Griffith, M.T., Katritch, V., Kunken, J., Xu, F., Cherezov, V., Hanson, M.A., Stevens, R.C., 2012. Fusion partner toolchest for the stabilization and crystallization of G protein-coupled receptors. Structure 20, 967-976. 
DeWire, S.M., Yamashita, D.S., Rominger, D.H., Liu, G., Cowan, C.L., Graczyk, T.M., Chen, X.T., Pitis, P.M., Gotchev, D., Yuan, C., Koblish, M., Lark, M.W., Violin, J.D., 2013. A G protein-biased ligand at the mu-opioid receptor is potently analgesic with reduced gastrointestinal and respiratory dysfunction compared with morphine. The Journal of pharmacology and experimental therapeutics 344, 708-717.

Dore, A.S., Okrasa, K., Patel, J.C., Serrano-Vega, M., Bennett, K., Cooke, R.M., Errey, J.C., Jazayeri, A., Khan, S., Tehan, B., Weir, M., Wiggin, G.R., Marshall, F.H., 2014. Structure of class C GPCR metabotropic glutamate receptor 5 transmembrane domain. Nature 511, $557-562$.

Fenalti, G., Giguere, P.M., Katritch, V., Huang, X.P., Thompson, A.A., Cherezov, V., Roth, B.L., Stevens, R.C., 2014. Molecular control of delta-opioid receptor signalling. Nature 506, 191-196.

Feng, Y., He, X., Yang, Y., Chao, D., Lazarus, L.H., Xia, Y., 2012. Current research on opioid receptor function. Current drug targets 13, 230-246.

Ferre, S., Casado, V., Devi, L.A., Filizola, M., Jockers, R., Lohse, M.J., Milligan, G., Pin, J.P., Guitart, X., 2014. G protein-coupled receptor oligomerization revisited: functional and pharmacological perspectives. Pharmacological reviews 66, 413-434.

Filizola, M., Devi, L.A., 2013. Grand opening of structure-guided design for novel opioids. Trends in pharmacological sciences 34, 6-12.

Fossepre, M., Leherte, L., Laaksonen, A., Vercauteren, D.P., 2014. On the Modularity of the Intrinsic Flexibility of the micro Opioid Receptor: A Computational Study. PloS one 9, e115856. 
Frolich, N., Dees, C., Paetz, C., Ren, X., Lohse, M.J., Nikolaev, V.O., Zenk, M.H., 2011. Distinct pharmacological properties of morphine metabolites at $\mathrm{G}(\mathrm{i})$-protein and betaarrestin signaling pathways activated by the human mu-opioid receptor. Biochemical pharmacology $81,1248-1254$.

Fujita, W., Gomes, I., Devi, L.A., 2014. Revolution in GPCR signalling: opioid receptor heteromers as novel therapeutic targets: IUPHAR review 10. British journal of pharmacology 171, 4155-4176.

Goldfeld, D.A., Murphy, R., Kim, B., Wang, L., Beuming, T., Abel, R., Friesner, R.A., 2015. Docking and free energy perturbation studies of ligand binding in the kappa opioid receptor. J Phys Chem B 119, 824-835.

Granier, S., Manglik, A., Kruse, A.C., Kobilka, T.S., Thian, F.S., Weis, W.I., Kobilka, B.K., 2012. Structure of the delta-opioid receptor bound to naltrindole. Nature 485, 400-404.

Haga, K., Kruse, A.C., Asada, H., Yurugi-Kobayashi, T., Shiroishi, M., Zhang, C., Weis, W.I., Okada, T., Kobilka, B.K., Haga, T., Kobayashi, T., 2012. Structure of the human M2 muscarinic acetylcholine receptor bound to an antagonist. Nature 482, 547-551.

Hanson, M.A., Roth, C.B., Jo, E., Griffith, M.T., Scott, F.L., Reinhart, G., Desale, H., Clemons, B., Cahalan, S.M., Schuerer, S.C., Sanna, M.G., Han, G.W., Kuhn, P., Rosen, H., Stevens, R.C., 2012. Crystal structure of a lipid G protein-coupled receptor. Science 335, 851-855.

He, S.Q., Zhang, Z.N., Guan, J.S., Liu, H.R., Zhao, B., Wang, H.B., Li, Q., Yang, H., Luo, J., Li, Z.Y., Wang, Q., Lu, Y.J., Bao, L., Zhang, X., 2011. Facilitation of mu-opioid receptor activity by preventing delta-opioid receptor-mediated codegradation. Neuron 69, 120-131. 
Hollenstein, K., Kean, J., Bortolato, A., Cheng, R.K., Dore, A.S., Jazayeri, A., Cooke, R.M., Weir, M., Marshall, F.H., 2013. Structure of class B GPCR corticotropin-releasing factor receptor 1. Nature 499, 438-443.

Jaakola, V.P., Griffith, M.T., Hanson, M.A., Cherezov, V., Chien, E.Y., Lane, J.R., Ijzerman, A.P., Stevens, R.C., 2008. The 2.6 angstrom crystal structure of a human A2A adenosine receptor bound to an antagonist. Science 322, 1211-1217.

Jacobson, K.A., 2013. Structure-based approaches to ligands for G-protein-coupled adenosine and P2Y receptors, from small molecules to nanoconjugates. J Med Chem 56, 3749-3767.

Johnston, J.M., Aburi, M., Provasi, D., Bortolato, A., Urizar, E., Lambert, N.A., Javitch, J.A., Filizola, M., 2011. Making structural sense of dimerization interfaces of delta opioid receptor homodimers. Biochemistry 50, 1682-1690.

Johnston, J.M., Filizola, M., 2014. Differential stability of the crystallographic interfaces of muand kappa-opioid receptors. PloS one 9, e90694.

Katritch, V., Fenalti, G., Abola, E.E., Roth, B.L., Cherezov, V., Stevens, R.C., 2014a. Allosteric sodium in class A GPCR signaling. Trends in biochemical sciences 39, 233-244.

Katritch, V., Fenalti, G., Abola, E.E., Roth, B.L., Cherezov, V., Stevens, R.C., 2014b. Allosteric sodium: a key co-factor in class A GPCR signaling. Trends in biochemical sciences.

Keith, D.E., Murray, S.R., Zaki, P.A., Chu, P.C., Lissin, D.V., Kang, L., Evans, C.J., von Zastrow, M., 1996. Morphine activates opioid receptors without causing their rapid internalization. The Journal of biological chemistry 271, 19021-19024.

Kooistra, A.J., Leurs, R., de Esch, I.J., de Graaf, C., 2014. From three-dimensional GPCR structure to rational ligand discovery. Adv Exp Med Biol 796, 129-157. 
Kreek, M.J., Levran, O., Reed, B., Schlussman, S.D., Zhou, Y., Butelman, E.R., 2012. Opiate addiction and cocaine addiction: underlying molecular neurobiology and genetics. The Journal of clinical investigation 122, 3387-3393.

Krissinel, E., Henrick, K., 2007. Inference of macromolecular assemblies from crystalline state. Journal of molecular biology 372, 774-797.

Kruse, A.C., Hu, J., Pan, A.C., Arlow, D.H., Rosenbaum, D.M., Rosemond, E., Green, H.F., Liu, T., Chae, P.S., Dror, R.O., Shaw, D.E., Weis, W.I., Wess, J., Kobilka, B.K., 2012. Structure and dynamics of the M3 muscarinic acetylcholine receptor. Nature 482, 552-556.

Lambert, N.A., Javitch, J.A., 2014a. CrossTalk opposing view: Weighing the evidence for class A GPCR dimers, the jury is still out. The Journal of physiology 592, 2443-2445.

Lambert, N.A., Javitch, J.A., 2014b. Rebuttal from Nevin A. Lambert and Jonathan A. Javitch. The Journal of physiology 592, 2449.

Land, B.B., Bruchas, M.R., Schattauer, S., Giardino, W.J., Aita, M., Messinger, D., Hnasko, T.S., Palmiter, R.D., Chavkin, C., 2009. Activation of the kappa opioid receptor in the dorsal raphe nucleus mediates the aversive effects of stress and reinstates drug seeking. Proceedings of the National Academy of Sciences of the United States of America 106, 19168-19173.

Leonis, G., Avramopoulos, A., Salmas, R.E., Durdagi, S., Yurtsever, M., Papadopoulos, M.G., 2014. Elucidation of conformational states, dynamics, and mechanism of binding in human kappa-opioid receptor complexes. Journal of chemical information and modeling 54, 22942308. 
Liu, W., Chun, E., Thompson, A.A., Chubukov, P., Xu, F., Katritch, V., Han, G.W., Roth, C.B., Heitman, L.H., AP, I.J., Cherezov, V., Stevens, R.C., 2012. Structural basis for allosteric regulation of GPCRs by sodium ions. Science 337, 232-236.

Luttrell, L.M., 2014. Minireview: More than just a hammer: ligand "bias" and pharmaceutical discovery. Mol Endocrinol 28, 281-294.

Lutz, P.E., Kieffer, B.L., 2013. Opioid receptors: distinct roles in mood disorders. Trends in neurosciences 36, 195-206.

Manglik, A., Kruse, A.C., Kobilka, T.S., Thian, F.S., Mathiesen, J.M., Sunahara, R.K., Pardo, L., Weis, W.I., Kobilka, B.K., Granier, S., 2012. Crystal structure of the mu-opioid receptor bound to a morphinan antagonist. Nature 485, 321-326.

Martinez-Mayorga, K., Byler, K.G., Yongye, A.B., Giulianotti, M.A., Dooley, C.T., Houghten, R.A., 2013. Ligand/kappa-opioid receptor interactions: insights from the X-ray crystal structure. European journal of medicinal chemistry 66, 114-121.

McCurdy, C.R., Prisinzano, T.E., Abraham, D.J., 2003. Opioid Receptor Ligands, Burger's Medicinal Chemistry and Drug Discovery. John Wiley \& Sons, Inc.

McPherson, J., Rivero, G., Baptist, M., Llorente, J., Al-Sabah, S., Krasel, C., Dewey, W.L., Bailey, C.P., Rosethorne, E.M., Charlton, S.J., Henderson, G., Kelly, E., 2010. mu-opioid receptors: correlation of agonist efficacy for signalling with ability to activate internalization. Molecular pharmacology 78, 756-766.

Molinari, P., Vezzi, V., Sbraccia, M., Gro, C., Riitano, D., Ambrosio, C., Casella, I., Costa, T., 2010. Morphine-like opiates selectively antagonize receptor-arrestin interactions. The Journal of biological chemistry 285, 12522-12535. 
Negri, A., Rives, M.L., Caspers, M.J., Prisinzano, T.E., Javitch, J.A., Filizola, M., 2013. Discovery of a novel selective kappa-opioid receptor agonist using crystal structure-based virtual screening. Journal of chemical information and modeling 53, 521-526.

O'Dowd, B.F., Ji, X., O'Dowd, P.B., Nguyen, T., George, S.R., 2012. Disruption of the mu-delta opioid receptor heteromer. Biochemical and biophysical research communications 422, 556560.

Palczewski, K., Kumasaka, T., Hori, T., Behnke, C.A., Motoshima, H., Fox, B.A., Le Trong, I., Teller, D.C., Okada, T., Stenkamp, R.E., Yamamoto, M., Miyano, M., 2000. Crystal structure of rhodopsin: A G protein-coupled receptor. Science 289, 739-745.

Pasternak, G.W., 2014. Opiate pharmacology and relief of pain. Journal of clinical oncology : official journal of the American Society of Clinical Oncology 32, 1655-1661.

Pasternak, G.W., Pan, Y.X., 2013. Mu opioids and their receptors: evolution of a concept. Pharmacological reviews 65, 1257-1317.

Pasternak, G.W., Snowman, A.M., Snyder, S.H., 1975. Selective enhancement of [3H]opiate agonist binding by divalent cations. Molecular pharmacology 11, 735-744.

Pasternak, G.W., Snyder, S.H., 1975. Identification of novel high affinity opiate receptor binding in rat brain. Nature 253, 563-565.

Pert, C.B., Pasternak, G., Snyder, S.H., 1973. Opiate agonists and antagonists discriminated by receptor binding in brain. Science 182, 1359-1361.

Polepally, P.R., Huben, K., Vardy, E., Setola, V., Mosier, P.D., Roth, B.L., Zjawiony, J.K., 2014. Michael acceptor approach to the design of new salvinorin A-based high affinity ligands for the kappa-opioid receptor. European journal of medicinal chemistry 85, 818-829. 
Preininger, A.M., Meiler, J., Hamm, H.E., 2013. Conformational flexibility and structural dynamics in GPCR-mediated G protein activation: a perspective. Journal of molecular biology 425, 2288-2298.

Raehal, K.M., Bohn, L.M., 2014. beta-arrestins: regulatory role and therapeutic potential in opioid and cannabinoid receptor-mediated analgesia. Handbook of experimental pharmacology 219, 427-443.

Raehal, K.M., Schmid, C.L., Groer, C.E., Bohn, L.M., 2011. Functional selectivity at the muopioid receptor: implications for understanding opioid analgesia and tolerance. Pharmacological reviews 63, 1001-1019.

Raehal, K.M., Walker, J.K., Bohn, L.M., 2005. Morphine side effects in beta-arrestin 2 knockout mice. The Journal of pharmacology and experimental therapeutics 314, 1195-1201.

Rivero, G., Llorente, J., McPherson, J., Cooke, A., Mundell, S.J., McArdle, C.A., Rosethorne, E.M., Charlton, S.J., Krasel, C., Bailey, C.P., Henderson, G., Kelly, E., 2012. Endomorphin2: a biased agonist at the mu-opioid receptor. Molecular pharmacology 82, 178-188.

Shang, Y., LeRouzic, V., Schneider, S., Bisignano, P., Pasternak, G.W., Filizola, M., 2014. Mechanistic insights into the allosteric modulation of opioid receptors by sodium ions. Biochemistry 53, 5140-5149.

Shim, J., Coop, A., MacKerell, A.D., Jr., 2013a. Molecular details of the activation of the mu opioid receptor. J Phys Chem B 117, 7907-7917.

Shim, J., Coop, A., MacKerell, A.D., Jr., 2013b. Molecular details of the activation of the mu opioid receptor. The journal of physical chemistry. B 117, 7907-7917. 
Shimamura, T., Shiroishi, M., Weyand, S., Tsujimoto, H., Winter, G., Katritch, V., Abagyan, R., Cherezov, V., Liu, W., Han, G.W., Kobayashi, T., Stevens, R.C., Iwata, S., 2011. Structure of the human histamine H1 receptor complex with doxepin. Nature 475, 65-70.

Shoichet, B.K., Kobilka, B.K., 2012. Structure-based drug screening for G-protein-coupled receptors. Trends in pharmacological sciences 33, 268-272.

Shonberg, J., Lopez, L., Scammells, P.J., Christopoulos, A., Capuano, B., Lane, J.R., 2014. Biased Agonism at G Protein-Coupled Receptors: The Promise and the Challenges-A Medicinal Chemistry Perspective. Medicinal research reviews.

Shukla, A.K., 2014. Biasing GPCR signaling from inside. Science signaling 7, pe3.

Siu, F.Y., He, M., de Graaf, C., Han, G.W., Yang, D., Zhang, Z., Zhou, C., Xu, Q., Wacker, D., Joseph, J.S., Liu, W., Lau, J., Cherezov, V., Katritch, V., Wang, M.W., Stevens, R.C., 2013. Structure of the human glucagon class B G-protein-coupled receptor. Nature 499, 444-449.

Soergel, D.G., Ann Subach, R., Sadler, B., Connell, J., Marion, A.S., Cowan, C.L., Violin, J.D., Lark, M.W., 2014a. First clinical experience with TRV130: pharmacokinetics and pharmacodynamics in healthy volunteers. J Clin Pharmacol 54, 351-357.

Soergel, D.G., Subach, R.A., Burnham, N., Lark, M.W., James, I.E., Sadler, B.M., Skobieranda, F., Violin, J.D., Webster, L.R., 2014b. Biased agonism of the mu-opioid receptor by TRV130 increases analgesia and reduces on-target adverse effects versus morphine: A randomized, double-blind, placebo-controlled, crossover study in healthy volunteers. Pain $155,1829-1835$.

Srivastava, A., Yano, J., Hirozane, Y., Kefala, G., Gruswitz, F., Snell, G., Lane, W., Ivetac, A., Aertgeerts, K., Nguyen, J., Jennings, A., Okada, K., 2014. High-resolution structure of the human GPR40 receptor bound to allosteric agonist TAK-875. Nature 513, 124-127. 
Sternini, C., Spann, M., Anton, B., Keith, D.E., Jr., Bunnett, N.W., von Zastrow, M., Evans, C., Brecha, N.C., 1996. Agonist-selective endocytosis of mu opioid receptor by neurons in vivo. Proceedings of the National Academy of Sciences of the United States of America 93, 92419246.

Tan, Q., Zhu, Y., Li, J., Chen, Z., Han, G.W., Kufareva, I., Li, T., Ma, L., Fenalti, G., Zhang, W., Xie, X., Yang, H., Jiang, H., Cherezov, V., Liu, H., Stevens, R.C., Zhao, Q., Wu, B., 2013. Structure of the CCR5 chemokine receptor-HIV entry inhibitor maraviroc complex. Science $341,1387-1390$.

Thompson, A.A., Liu, W., Chun, E., Katritch, V., Wu, H., Vardy, E., Huang, X.P., Trapella, C., Guerrini, R., Calo, G., Roth, B.L., Cherezov, V., Stevens, R.C., 2012. Structure of the nociceptin/orphanin FQ receptor in complex with a peptide mimetic. Nature 485, 395-399.

Thompson, G.L., Canals, M., Poole, D.P., 2014. Biological redundancy of endogenous GPCR ligands in the gut and the potential for endogenous functional selectivity. Frontiers in pharmacology $5,262$.

Thompson, G.L., Kelly, E., Christopoulos, A., Canals, M., 2015. Novel GPCR paradigms at the mu-opioid receptor. British journal of pharmacology 172, 287-296.

Vanderah, T.W., 2010. Delta and kappa opioid receptors as suitable drug targets for pain. The Clinical journal of pain 26 Suppl 10, S10-15.

Vardy, E., Mosier, P.D., Frankowski, K.J., Wu, H., Katritch, V., Westkaemper, R.B., Aube, J., Stevens, R.C., Roth, B.L., 2013. Chemotype-selective modes of action of kappa-opioid receptor agonists. The Journal of biological chemistry 288, 34470-34483.

Violin, J.D., Crombie, A.L., Soergel, D.G., Lark, M.W., 2014. Biased ligands at G-proteincoupled receptors: promise and progress. Trends in pharmacological sciences 35, 308-316. 
Vortherms, T.A., Roth, B.L., 2005. Receptorome screening for CNS drug discovery. IDrugs : the investigational drugs journal 8, 491-496.

Wacker, D., Wang, C., Katritch, V., Han, G.W., Huang, X.P., Vardy, E., McCorvy, J.D., Jiang, Y., Chu, M., Siu, F.Y., Liu, W., Xu, H.E., Cherezov, V., Roth, B.L., Stevens, R.C., 2013. Structural features for functional selectivity at serotonin receptors. Science 340, 615-619.

Wang, C., Jiang, Y., Ma, J., Wu, H., Wacker, D., Katritch, V., Han, G.W., Liu, W., Huang, X.P., Vardy, E., McCorvy, J.D., Gao, X., Zhou, X.E., Melcher, K., Zhang, C., Bai, F., Yang, H., Yang, L., Jiang, H., Roth, B.L., Cherezov, V., Stevens, R.C., Xu, H.E., 2013a. Structural basis for molecular recognition at serotonin receptors. Science 340, 610-614.

Wang, C., Wu, H., Katritch, V., Han, G.W., Huang, X.P., Liu, W., Siu, F.Y., Roth, B.L., Cherezov, V., Stevens, R.C., 2013b. Structure of the human smoothened receptor bound to an antitumour agent. Nature 497, 338-343.

Wang, Y.H., Sun, J.F., Tao, Y.M., Chi, Z.Q., Liu, J.G., 2010. The role of kappa-opioid receptor activation in mediating antinociception and addiction. Acta pharmacologica Sinica 31, 1065-1070.

Warne, T., Serrano-Vega, M.J., Baker, J.G., Moukhametzianov, R., Edwards, P.C., Henderson, R., Leslie, A.G., Tate, C.G., Schertler, G.F., 2008. Structure of a beta1-adrenergic Gprotein-coupled receptor. Nature 454, 486-491.

White, J.F., Noinaj, N., Shibata, Y., Love, J., Kloss, B., Xu, F., Gvozdenovic-Jeremic, J., Shah, P., Shiloach, J., Tate, C.G., Grisshammer, R., 2012. Structure of the agonist-bound neurotensin receptor. Nature 490, 508-513. 
White, K.L., Scopton, A.P., Rives, M.L., Bikbulatov, R.V., Polepally, P.R., Brown, P.J., Kenakin, T., Javitch, J.A., Zjawiony, J.K., Roth, B.L., 2014. Identification of novel functionally selective kappa-opioid receptor scaffolds. Molecular pharmacology 85, 83-90.

Williams, J.T., Ingram, S.L., Henderson, G., Chavkin, C., von Zastrow, M., Schulz, S., Koch, T., Evans, C.J., Christie, M.J., 2013. Regulation of mu-opioid receptors: desensitization, phosphorylation, internalization, and tolerance. Pharmacological reviews 65, 223-254.

Wu, B., Chien, E.Y., Mol, C.D., Fenalti, G., Liu, W., Katritch, V., Abagyan, R., Brooun, A., Wells, P., Bi, F.C., Hamel, D.J., Kuhn, P., Handel, T.M., Cherezov, V., Stevens, R.C., 2010. Structures of the CXCR4 chemokine GPCR with small-molecule and cyclic peptide antagonists. Science 330, 1066-1071.

Wu, H., Wacker, D., Mileni, M., Katritch, V., Han, G.W., Vardy, E., Liu, W., Thompson, A.A., Huang, X.P., Carroll, F.I., Mascarella, S.W., Westkaemper, R.B., Mosier, P.D., Roth, B.L., Cherezov, V., Stevens, R.C., 2012. Structure of the human kappa-opioid receptor in complex with JDTic. Nature 485, 327-332.

Wu, H., Wang, C., Gregory, K.J., Han, G.W., Cho, H.P., Xia, Y., Niswender, C.M., Katritch, V., Meiler, J., Cherezov, V., Conn, P.J., Stevens, R.C., 2014. Structure of a class C GPCR metabotropic glutamate receptor 1 bound to an allosteric modulator. Science 344, 58-64.

Yin, J., Mobarec, J.C., Kolb, P., Rosenbaum, D.M., 2014. Crystal structure of the human OX orexin receptor bound to the insomnia drug suvorexant. Nature.

Yuan, S., Vogel, H., Filipek, S., 2013. The role of water and sodium ions in the activation of the mu-opioid receptor. Angew Chem Int Ed Engl 52, 10112-10115. 
Zhang, C., Srinivasan, Y., Arlow, D.H., Fung, J.J., Palmer, D., Zheng, Y., Green, H.F., Pandey, A., Dror, R.O., Shaw, D.E., Weis, W.I., Coughlin, S.R., Kobilka, B.K., 2012. Highresolution crystal structure of human protease-activated receptor 1. Nature 492, 387-392.

Zhang, K., Zhang, J., Gao, Z.G., Zhang, D., Zhu, L., Han, G.W., Moss, S.M., Paoletta, S., Kiselev, E., Lu, W., Fenalti, G., Zhang, W., Muller, C.E., Yang, H., Jiang, H., Cherezov, V., Katritch, V., Jacobson, K.A., Stevens, R.C., Wu, B., Zhao, Q., 2014. Structure of the human P2Y12 receptor in complex with an antithrombotic drug. Nature 509, 115-118.

Zhou, L., Bohn, L.M., 2014. Functional selectivity of GPCR signaling in animals. Current opinion in cell biology 27, 102-108.

Zhou, L., Lovell, K.M., Frankowski, K.J., Slauson, S.R., Phillips, A.M., Streicher, J.M., Stahl, E., Schmid, C.L., Hodder, P., Madoux, F., Cameron, M.D., Prisinzano, T.E., Aube, J., Bohn, L.M., 2013. Development of functionally selective, small molecule agonists at kappa opioid receptors. The Journal of biological chemistry 288, 36703-36716. 


\section{Figure Legends}

Figure 1. Time-line of representative crystal structures of GPCR subtypes. Each representative crystal structure is shown in cartoon representation, with the bound ligand shown as colored spheres. With the exception of opioid receptors, which are colored in red, all the others are depicted in silver. Rhodopsin, Secretin, Glutamate, and Frizzled subfamilies of receptors are indicated with purple, cyan, green, and magenta colors, respectively. PDB IDs of the crystal structures are included in parenthesis after each protein name. Specifically, the reported crystal structures are (in chronological order): rhodopsin (1F88 (Palczewski et al., 2000)), $\beta_{2}$ Adrenergic (2RH1 (Cherezov et al., 2007)), $\quad \beta_{1}$ Adrenergic (2VT4 (Warne et al., 2008)), Adenosine $\mathrm{A}_{2 \mathrm{~A}}$ (3EML (Jaakola et al., 2008)), Chemokine CXCR4 (3ODU (Wu et al., 2010)), Dopamine $\mathrm{D}_{3}$ (3PBL (Chien et al., 2010)), Histamine $\mathrm{H}_{1}$ (3RZE (Shimamura et al., 2011)), Sphingosine-1phosphate receptor 1 (3V2Y (Hanson et al., 2012)), M2 Muscarinic (3UON (Haga et al., 2012)), M3 Muscarinic (4DAJ (Kruse et al., 2012)), Neurotensin NTSR1 (4GRV (White et al., 2012)), $\mu$ receptor (4DKL (Manglik et al., 2012)), $\delta$ receptor (4EJ4 (Granier et al., 2012)), $\kappa$ receptor (4DJH (Wu et al., 2012)), NOP receptor (4EA3 (Thompson et al., 2012)), Protease activated receptor 1 (3VW7 (Zhang et al., 2012)), 5HT 1 (4IAR (Wang et al., 2013a)), 5HT 2 (4IB4 (Wacker et al., 2013)), SMO (4JKV (Wang et al., 2013b)), Glucagon (4L6R (Siu et al., 2013)), CRF1R (4K5Y (Hollenstein et al., 2013)), Chemokine CCR5 (4MBS (Tan et al., 2013)), mGluR1 (4OR2 (Wu et al., 2014)), P2Y12 (4NTJ (Zhang et al., 2014)), mGluR 5 (4OO9 (Dore et al., 2014)), GPR40/FFAR1 (4PHU (Srivastava et al., 2014)), and Orexin OX2R (4S0V (Yin et al., 2014)). 
Figure 2. FTMAP results using $\delta(A), \mu(B)$, and $\kappa(C)$ receptor crystal structures. Only chains A of the receptors, excluding non-receptor atoms, were uploaded to the FTMAP web server for fragment docking calculation. Receptors are shown in silver cartoon representation, ligands in the crystal structures are shown in silver sticks, and FTMAP probe clusters are shown as colored lines. The FTMAP probe clusters are colored in the order of decreasing size as follows: green, cyan, magenta, yellow, red, blue, purple, orange, dark green, and chocolate.

Figure 3. Putative dimer interfaces inferred by existing GPCR crystal structures. Protein name and interface type are reported under each dimeric structure. PDB ID and interface area are included in parenthesis. Dimers are boxed (gray color) according to interface type. Opioid receptors are indicated by a red rounded rectangle, as well as red text. The interface area between protomers was calculated using the PISA web server (Krissinel and Henrick, 2007). All nonreceptor atoms were excluded from this calculation. 


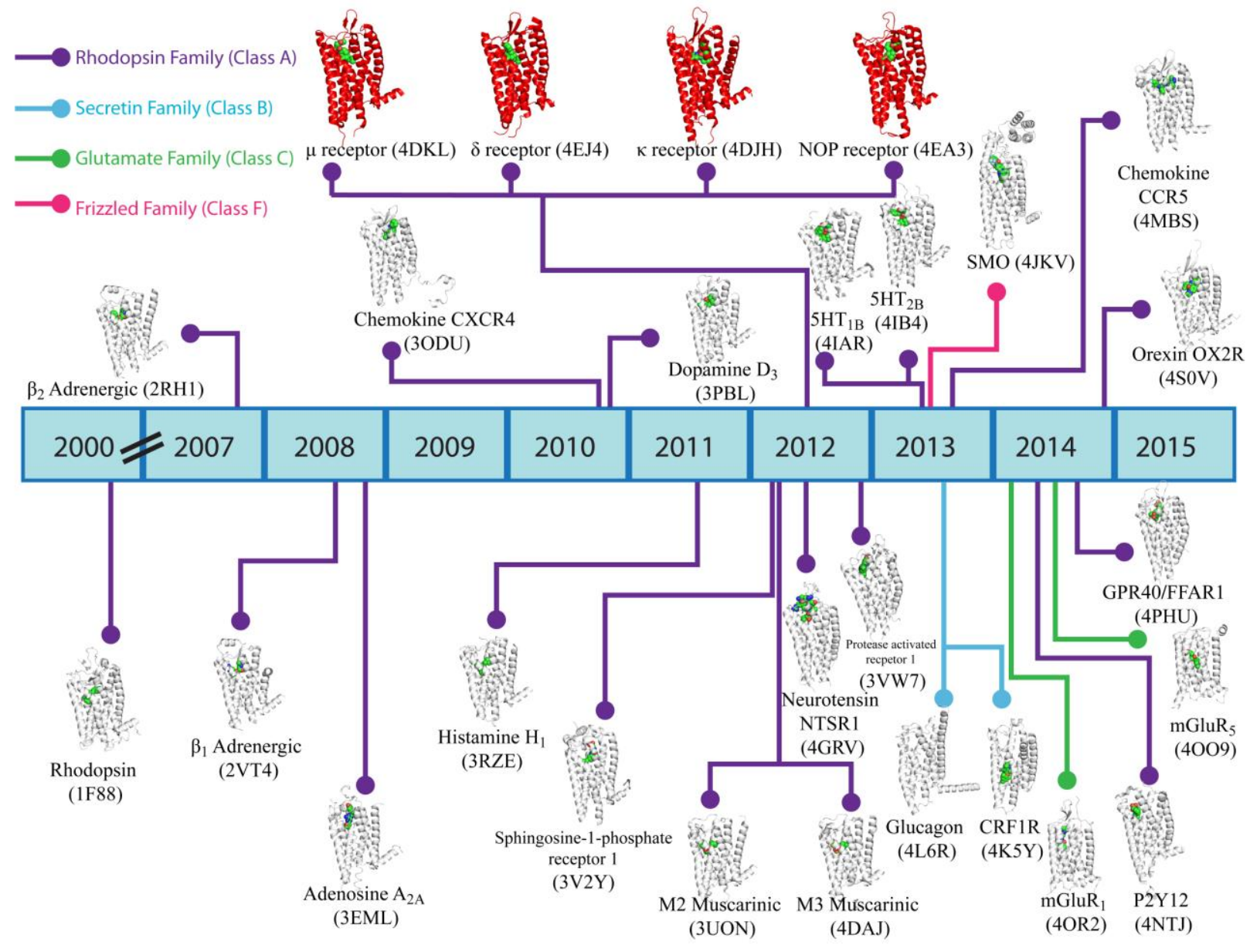

Figure 1 

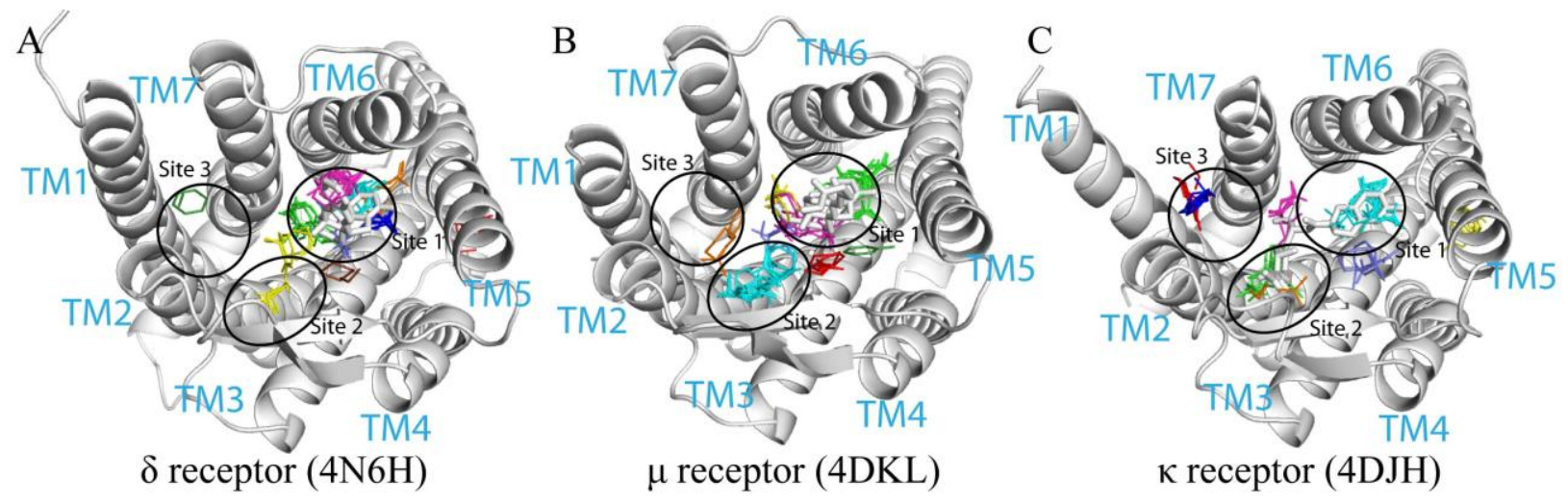

Figure 2 


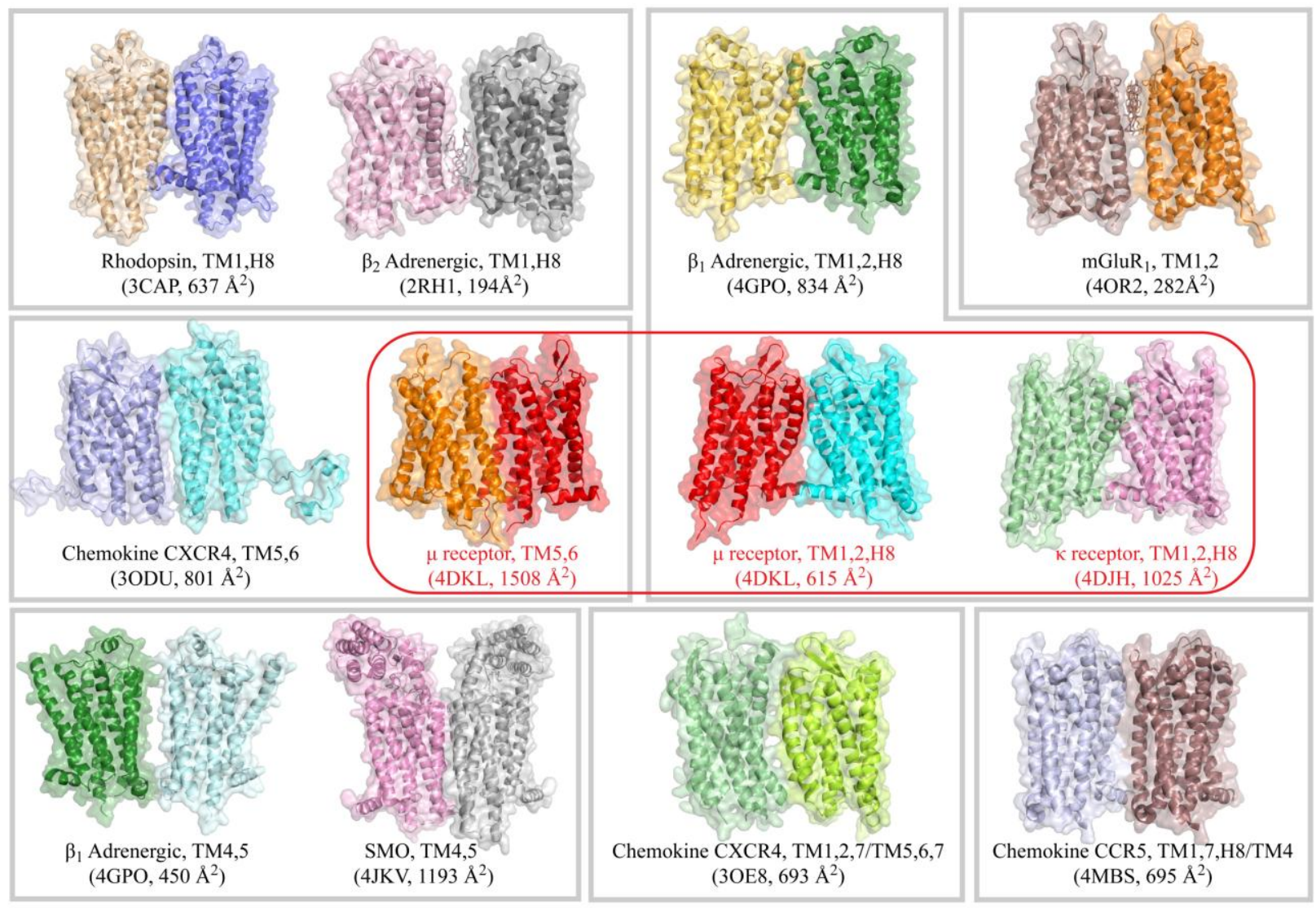

Figure 3 